\title{
Structural, Electrical, and Optical Properties of Reactively Sputtered Ag-Cu-O Films
}

\author{
P. Narayana Reddy, A. Sreedhar, M. Hari Prasad Reddy, and S. Uthanna \\ Department of Physics, Sri Venkateswara University, Tirupati 517 502, India \\ Correspondence should be addressed to P. Narayana Reddy, pnreddy66@gmail.com
}

Received 14 July 2012; Accepted 31 July 2012

Academic Editors: C. Bauerle, C. Homes, and A. N. Kocharian

Copyright ( $) 2012$ P. Narayana Reddy et al. This is an open access article distributed under the Creative Commons Attribution License, which permits unrestricted use, distribution, and reproduction in any medium, provided the original work is properly cited.

Thin films of silver-copper-oxide were deposited on glass substrates by RF magnetron sputtering of $\mathrm{Ag}_{80} \mathrm{Cu}_{20}$ target under various oxygen partial pressures in the range $5 \times 10^{-3}-8 \times 10^{-2} \mathrm{~Pa}$. The effect of oxygen partial pressure on the crystallographic structure and surface morphology and electrical and optical properties was systematically studied and the results were reported. The oxygen content in the films was correlated with the oxygen partial pressure maintained during the growth of the films. The films which formed at low oxygen partial pressure of $5 \times 10^{-3} \mathrm{~Pa}$ were mixed in phase of $\mathrm{Ag}_{2} \mathrm{Cu}_{2} \mathrm{O}_{3}$ and $\mathrm{Ag}$ while those deposited at $2 \times 10^{-2} \mathrm{~Pa}$ were grown with $\mathrm{Ag}_{2} \mathrm{Cu}_{2} \mathrm{O}_{3}$ and $\mathrm{Ag}_{2} \mathrm{Cu}_{2} \mathrm{O}_{4}$ phases. The films which formed at oxygen partial pressure of $2 \times 10^{-2} \mathrm{~Pa}$ showed electrical resistivity of $2.3 \Omega \mathrm{cm}$ and optical band gap of $1.47 \mathrm{eV}$.

\section{Introduction}

The silver-copper-oxygen ( $\mathrm{Ag}-\mathrm{Cu}-\mathrm{O})$ system consists of various ternary compounds $\mathrm{Ag}_{2} \mathrm{Cu}_{2} \mathrm{O}_{3}, \mathrm{Ag}_{2} \mathrm{Cu}_{2} \mathrm{O}_{4}$, and $\mathrm{AgCuO}_{2}$. In 1999 the first ternary silver copper oxide compound, $\mathrm{Ag}_{2} \mathrm{Cu}_{2} \mathrm{O}_{3}$ was prepared by Gomez-Romero et al. [1] in powder form by using a coprecipitation method at room temperature. Later in the second ternary silver copper oxide compound, $\mathrm{Ag}_{2} \mathrm{Cu}_{2} \mathrm{O}_{4}$ was synthesized by electrochemical oxidation of suspension of the precursor $\mathrm{Ag}_{2} \mathrm{Cu}_{2} \mathrm{O}_{3}$ [2-5] at room temperature and ozone oxidation [6]. Curda et al. $[7,8]$ synthesized mixed silver copper monoxide, $\mathrm{AgCuO}_{2}$, which is diamagnetic and showed mixed valence again, with the formula of $\mathrm{Ag}^{\mathrm{I}} \mathrm{Cu}^{\mathrm{II}} \mathrm{O}_{2}$. Most of the recent studies on silver copper oxides concentrated mainly on the determination of physical properties such as the crystal structure and thermal stability. There has been a shift towards looking at applications, with groups studying silver copper oxides as positive electrode in button cell batteries [9-12] or as new promising materials for photovoltaic applications. The silver copper oxides are p-type semiconductors, which could potentially be used as absorber material for future generation photovoltaic devices [13]. The ternary oxide of silver and copper also has novel applications in the fields of science and technology such as high Tc-super conductors [14].

Various thin films deposition techniques such as thermal oxidation of metallic films, pulsed laser deposition and sputtering were employed for the growth of metallic oxide films. Among these methods, magnetron sputtering technique is industrially practiced technique for the growth of thin films on larger area substrates. The physical properties of magnetron sputter deposited metal oxide films depend mainly on the process parameters such as oxygen partial pressure, substrate temperature, substrate bias voltage, sputter power and sputter pressure. The effect of substrate temperature on the structural, electrical, and optical properties of RF magnetron sputtered $\mathrm{Ag}-\mathrm{Cu}-\mathrm{O}$ films was reported earlier [15]. In this investigation, thin films of $\mathrm{Ag}-\mathrm{Cu}-\mathrm{O}$ were deposited on glass substrates by RF magnetron sputtering of $\mathrm{Ag}_{80} \mathrm{Cu}_{20}$ target at different oxygen partial pressures. The influence of oxygen partial pressure on the crystallographic structure, surface morphology, electrical and optical properties of the deposited Ag-Cu-O films was systematically studied and reported the results. 
TABle 1: Deposition parameters for the growth of Ag-Cu-O thin films.

\begin{tabular}{lc}
\hline Sputter target & $\begin{array}{c}\mathrm{Ag}_{80} \mathrm{Cu}_{20}(50 \mathrm{~mm} \text { diameter } \\
\text { and } 3 \mathrm{~mm} \text { thick })\end{array}$ \\
Ultimate pressure & $2 \times 10^{-4} \mathrm{~Pa}$ \\
Target to substrate distance & $65 \mathrm{~mm}$ \\
Oxygen partial pressure $\left(\mathrm{pO}_{2}\right)$ & $5 \times 10^{-3}-5 \times 10^{-2} \mathrm{~Pa}$ \\
Sputter pressure & $4 \mathrm{~Pa}$ \\
Substrate temperature & $303 \mathrm{~K}$ \\
Sputter power & $65 \mathrm{~W}$ \\
\hline
\end{tabular}

\section{Experimental}

Ag-Cu-O films were deposited on glass substrates by employing RF magnetron sputtering from a home-made circular planer magnetron sputtering system. The magnetron sputtering system is capable of producing base pressure of $5 \times 10^{-4} \mathrm{~Pa}$ using diffusion pump and rotary pump combination. The pressure in the sputter chamber was measured with digital Pirani-Penning gauge combination. Pure $\mathrm{Ag}_{80} \mathrm{Cu}_{20}$ target of $50 \mathrm{~mm}$ diameter was used for deposition of experimental films. Pure argon was used as sputter gas and oxygen as reactive gas. Two Aalborg mass flow controllers were used to control the flow rates of sputter gas of argon and reactive gas of oxygen individually. The sputter power of $65 \mathrm{~W}$ was fed to the sputter target with Advanced Energy RF power generator. Ag-Cu-O films were deposited on glass substrates held at room temperature $(303 \mathrm{~K})$ and at different oxygen partial pressures in the range $5 \times 10^{-3}$ $5 \times 10^{-2} \mathrm{~Pa}$. The process parameters maintained during the growth of the films are given in Table 1.

The deposited films were characterized by studying crystallographic structure and surface morphology, electrical and optical properties. The chemical composition of the films was determined by employing X-ray energy dispersive spectroscopic analyses (EDS) attached to the scanning electron microscope (Phillips XL 30S field effect gun). The crystallographic structure of the films was determined with the glancing angle X-ray diffraction (XRD) taken on a Bruker D8 Advance Diffractometer at the glancing angle of $4^{\circ}$ using monochromatic $\mathrm{CuK}_{\alpha_{1}}$ radiation. The surface morphology of the films was analysed by employing atomic force microscope (AFM). The electrical resistivity of the films was measured at room temperature using four-probe method (Jandel multiposition wafer probe). The optical transmittance of the films was recorded using PerkinElmer UV-Vis-NIR double beam spectrophotometer in the wavelength range $300-2500 \mathrm{~nm}$.

\section{Results and Discussion}

The thickness of the deposited films measured using Veeco Dektak (model 150) profilometer was in the range 210$250 \mathrm{~nm}$. The deposition rate of the films was determined from the film thickness and duration of the deposition. Figure 1 shows the dependence of deposition rate on the

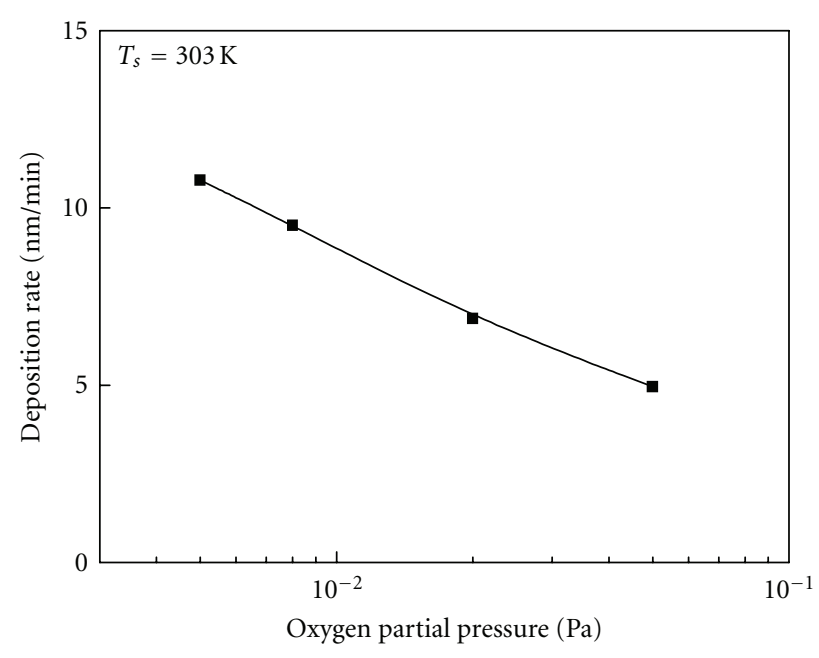

Figure 1: Variation in deposition rate of $\mathrm{Ag}-\mathrm{Cu}-\mathrm{O}$ films with the oxygen partial pressure.

oxygen partial pressure of the deposited films. The deposition rate of the films up to the oxygen partial pressures of $5 \times 10^{-3} \mathrm{~Pa}$ was about $10.5 \mathrm{~nm} / \mathrm{min}$. The deposition rate of the films formed at oxygen partial pressure of $5 \times$ $10^{-2} \mathrm{~Pa}$ decreased to $5.5 \mathrm{~nm} / \mathrm{min}$ and at higher oxygen partial pressures it remains almost constant. The high deposition rate at low oxygen partial pressures was due to the high sputtering yield of metallic silver-copper and insufficient oxygen available in the sputter chamber to react and to form silver-copper-oxide. The decrease in the deposition rate with increase of oxygen partial pressure was due to the decrease of sputter yield in the presence of reactive gas of oxygen and formation of $\mathrm{Ag}-\mathrm{Cu}-\mathrm{O}$ films. For moderate to highly reactive chemical system, the reactive sputter process comes with the abrupt decrease in the films deposition rate when the process turned into the so-called reactive sputter mode [16]. Such a decrease in the deposition rate with the increase of oxygen partial pressure was also reported in the deposition of DC reactive magnetron sputtered silver oxide films [17] formed with silver target, cuprous oxide films [18] formed with copper target and $\mathrm{Ag}-\mathrm{Cu}-\mathrm{O}$ films with $\mathrm{Ag}_{50} \mathrm{Cu}_{50}$ target [19].

Figure 2 shows the representative $\mathrm{X}$-ray energy dispersive spectrum of the Ag-Cu-O film formed of oxygen partial pressure of $2 \times 10^{-2} \mathrm{~Pa}$. The $\mathrm{X}$-ray energy dispersive spectroscopic analysis indicated that the oxygen content in the films was correlated with the oxygen partial pressure maintained in the sputter chamber. The atomic ratio of copper to silver was nearly constant value of $0.208 \pm 0.010$. At low oxygen partial pressure of $5 \times 10^{-3} \mathrm{~Pa}$ the oxygen content in the films was 38.6 at. \%. The films deposited at oxygen partial pressure of $2 \times 10^{-2} \mathrm{~Pa}$ was 49.4 at. $\%$ and at higher pressures it remains almost constant [19].

The X-ray diffraction profiles of the films deposited at different oxygen partial pressures are shown in Figure 3. The films deposited at low oxygen partial pressure of $5 \times 10^{-3} \mathrm{~Pa}$ were X-ray amorphous with presence of weak diffraction peaks related to the $\mathrm{Ag}_{2} \mathrm{Cu}_{2} \mathrm{O}_{3}$ (JCPDS no. 00-004-0783) 


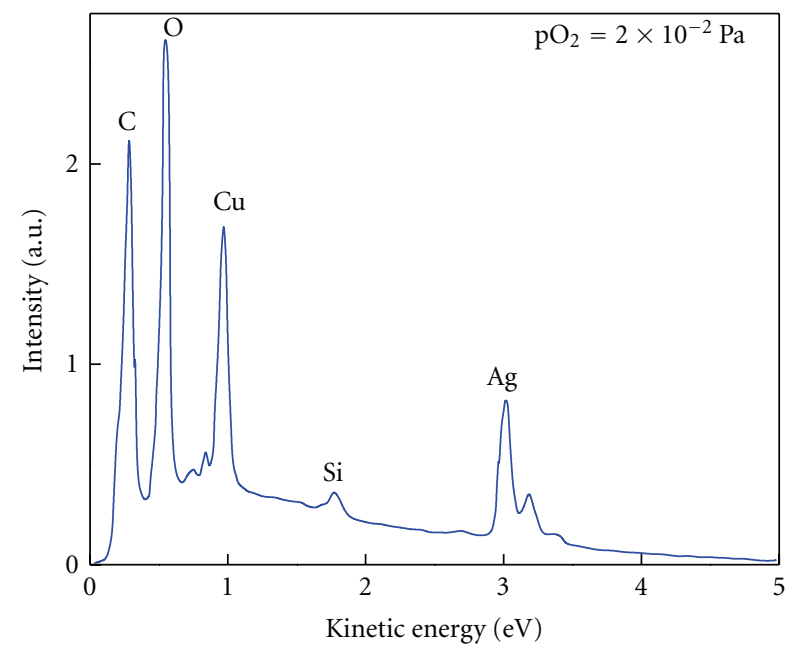

Figure 2: A representative EDS spectrum of $\mathrm{Ag}-\mathrm{Cu}-\mathrm{O}$ film formed at oxygen partial pressure of $2 \times 10^{-2} \mathrm{~Pa}$.

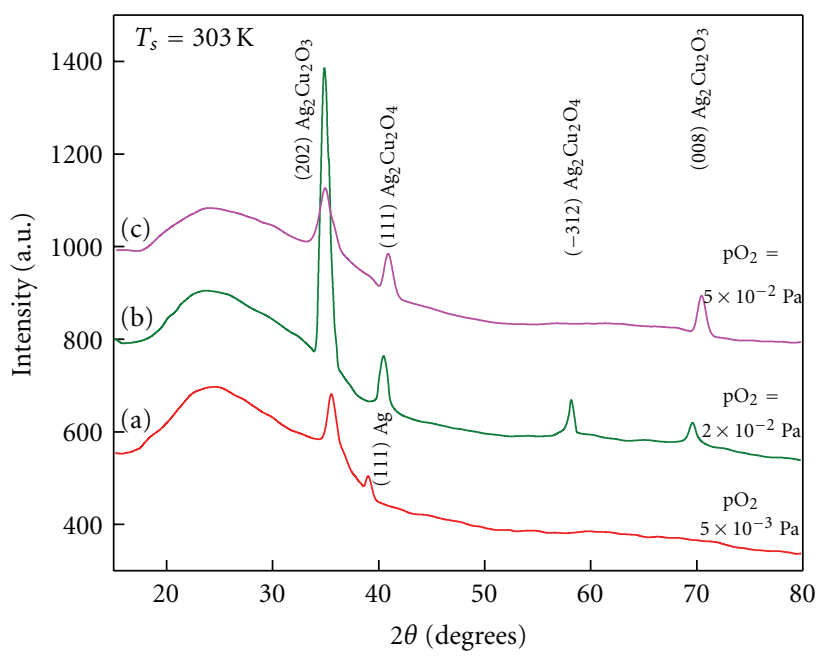

Figure 3: X-ray diffraction profiles of Ag-Cu-O films formed at different oxygen partial pressures.

and Ag (JCPDS no. 01-073-6753). The presence of mixed phase of $\mathrm{Ag}_{2} \mathrm{Cu}_{2} \mathrm{O}_{3}$ and $\mathrm{Ag}$ was due to the insufficient oxygen available in the sputter chamber during the deposition of the films. When the oxygen partial pressure increased to 2 $\times 10^{-2} \mathrm{~Pa}$, the films were of polycrystalline in nature. The additional peak seen at $2 \theta=58^{\circ}$ was related to the $(-312)$ reflections of $\mathrm{Ag}_{2} \mathrm{Cu}_{2} \mathrm{O}_{4}$ (JCPDS no. 01-073-7193) and $69^{\circ}$ connected to the (008) reflection of $\mathrm{Ag}_{2} \mathrm{Cu}_{2} \mathrm{O}_{3}$ (JCPDS no. 00-004-0783).

It revealed that the films formed at oxygen partial pressure of $2 \times 10^{-2} \mathrm{~Pa}$ were mixed phase of $\mathrm{Ag}_{2} \mathrm{Cu}_{2} \mathrm{O}_{3}$ and $\mathrm{Ag}_{2} \mathrm{Cu}_{2} \mathrm{O}_{4}$ with the absence of elemental Ag. Despite further increase of oxygen partial pressure to $5 \times 10^{-2} \mathrm{~Pa}$, there was enhancement in the intensity of the (111) reflection of $\mathrm{Ag}_{2} \mathrm{Cu}_{2} \mathrm{O}_{4}$ with a reduction in the intensity of (202) reflection of $\mathrm{Ag}_{2} \mathrm{Cu}_{2} \mathrm{O}_{3}$ [19]. The crystallite size $(L)$ of the films was evaluated from the full width at half maximum intensity of X-ray diffraction peaks of (202) $\mathrm{Ag}_{2} \mathrm{Cu}_{2} \mathrm{O}_{3}$ using the Debye-Scherrer's relation:

$$
L=\frac{k \lambda}{\beta \cos \theta},
$$

where $k$ is a constant with value of 0.89 for copper $\mathrm{K}_{\alpha}$ radiation and $\beta$ the full width at half maximum intensity of $\mathrm{X}$-ray diffraction peak. The crystallite size of the films formed at oxygen partial pressure of $2 \times 10^{-2} \mathrm{~Pa}$ was about $15 \mathrm{~nm}$. Despite further increase of oxygen partial pressure to $5 \times$ $10^{-2} \mathrm{~Pa}$, the crystalline size of the films decreased to $10 \mathrm{~nm}$.

Figure 4 shows atomic force micrographs of $\mathrm{Ag}-\mathrm{Cu}-\mathrm{O}$ films formed at different oxygen partial pressures. The films deposited at low oxygen partial pressure of $5 \times 10^{-3} \mathrm{~Pa}$ showed irregular shape of grains with grain size of $35 \mathrm{~nm}$ and the root mean square roughness of $1.3 \mathrm{~nm}$. It is also seen that the films were not uniform with many stick up particles, and it may be the presence of silver clusters due to low oxygen partial pressure. The films formed at oxygen partial pressure of $2 \times 10^{-2} \mathrm{~Pa}$ showed fine grain structure. At oxygen partial pressure of $5 \times 10^{-2} \mathrm{~Pa}$, the formed films were of larger size grains. The grain size of the films increased from 35 to $132 \mathrm{~nm}$ with the increase of oxygen partial pressure from 5 $\times 10^{-3}$ to $5 \times 10^{-2} \mathrm{~Pa}$. The root mean square surface of the films increased from 1.3 to $4.3 \mathrm{~nm}$ with increase of oxygen partial pressure from $5 \times 10^{-3}$ to $5 \times 10^{-2} \mathrm{~Pa}$. Figure 5 shows the variation in grain size and surface roughness of Ag-Cu-O films with the oxygen partial pressure.

The variation of electrical resistivity of $\mathrm{Ag}-\mathrm{Cu}-\mathrm{O}$ films with the oxygen partial pressure is shown in Figure 6. The electrical resistivity of the films formed at low oxygen partial pressure of $5 \times 10^{-3} \mathrm{~Pa}$ was $1.8 \times 10^{-1} \Omega \mathrm{cm}$. The electrical resistivity of the films increased to $2.3 \Omega \mathrm{cm}$ with the increase of oxygen pressure to $2 \times 10^{-2} \mathrm{~Pa}$. Despite further increase of oxygen partial pressure to $5 \times 10^{-2} \mathrm{~Pa}$, the electrical resistivity increased to $1.2 \times 10^{2} \Omega \mathrm{cm}$.

The electrical resistivity of pure silver was $1.6 \times$ $10^{-6} \Omega \mathrm{cm}$. The $\mathrm{Ag}_{2} \mathrm{O}$ films formed by RF magnetron sputtering at oxygen partial pressure of $2 \times 10^{-2} \mathrm{~Pa}$ was $3 \times$ $10^{-3} \Omega \mathrm{cm}$ [20]. Ravi Chandra Raju et al. [21] reported that the electrical resistivity of pulsed laser deposited AgO films was close to $2 \times 10^{5} \Omega \mathrm{cm}$. The low electrical resistivity of $1.8 \times 10^{-1} \Omega \mathrm{cm}$ at low oxygen partial pressure of $5 \times$ $10^{-3} \mathrm{~Pa}$ was due to the presence of metallic silver along with $\mathrm{Ag}_{2} \mathrm{Cu}_{2} \mathrm{O}_{3}$ phase. The increase in the electrical resistivity value of $2.3 \Omega \mathrm{cm}$ at oxygen partial pressure of $2 \times 10^{-2} \mathrm{~Pa}$ was due to the formation of mixed phase of silver copper oxide films. Despite further increase of oxygen partial pressure to $5 \times 10^{-2} \mathrm{~Pa}$, the increase of electrical resistivity may be due to the reduction in the crystallinity as shown in the XRD profile data. It is to be noted that the RF magnetron sputtered $\mathrm{Ag}_{2} \mathrm{Cu}_{2} \mathrm{O}_{3}$ films formed with $\mathrm{Ag}_{70} \mathrm{Cu}_{30}$ target at oxygen partial pressure showed electrical resistivity $8.2 \Omega \mathrm{cm}[20]$.

Figure 7 shows the wavelength dependence of optical transmittance of the films formed at different oxygen partial pressures. The films formed at low oxygen partial pressure of $5 \times 10^{-3} \mathrm{~Pa}$ exhibited the low optical transmittance due 


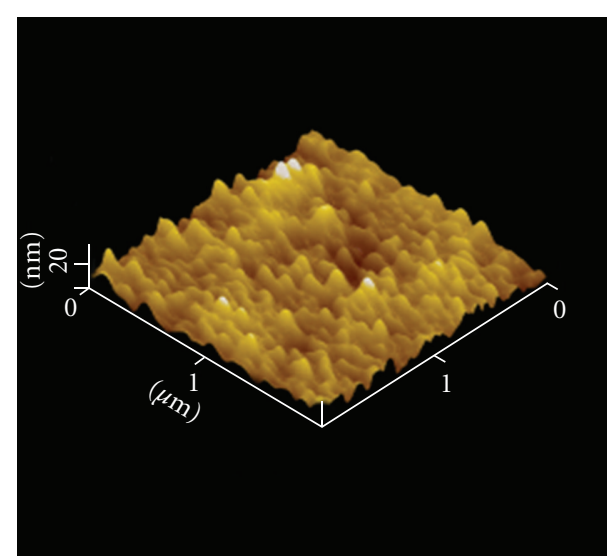

(c)

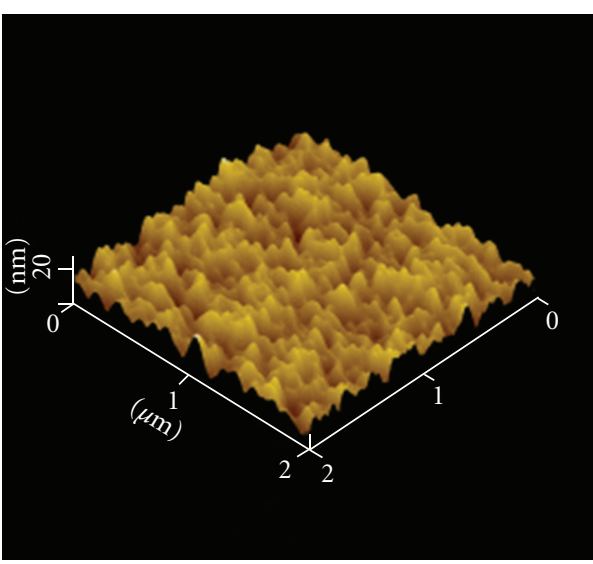

(b)

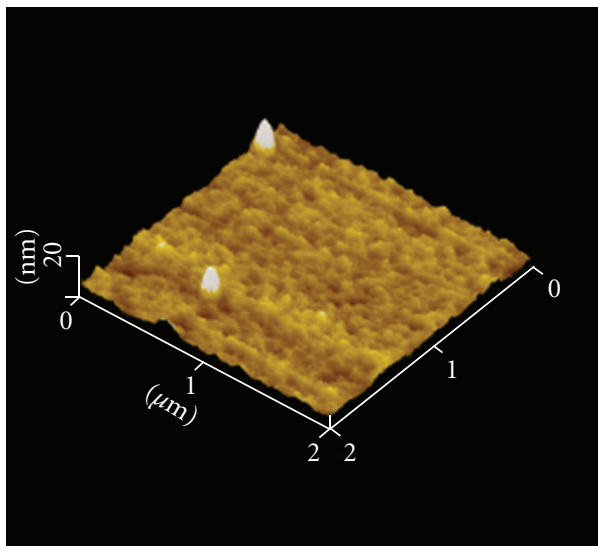

(a)

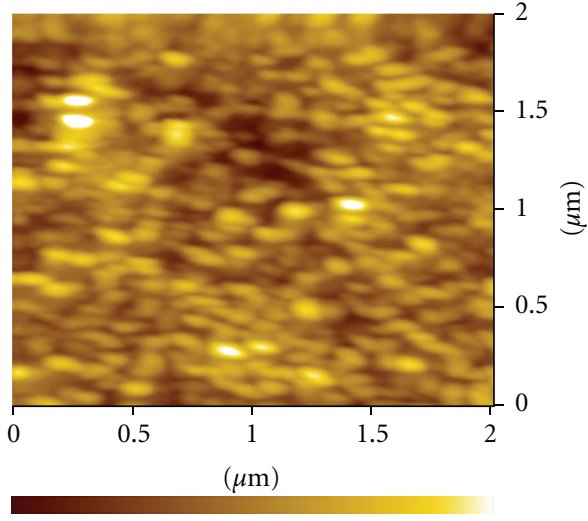

$(\mathrm{nm})$

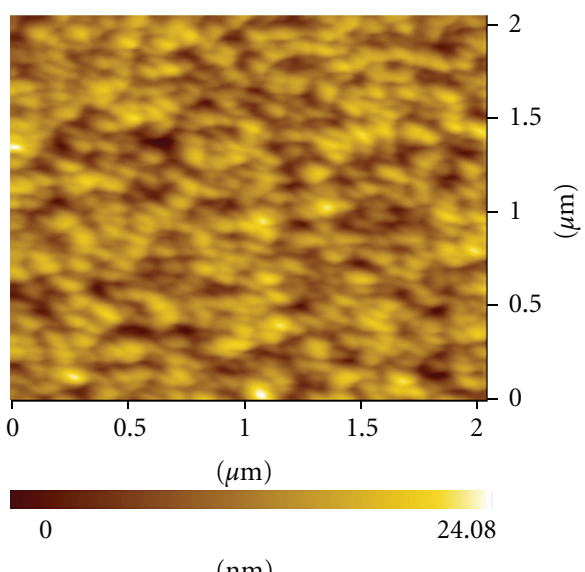

$(\mathrm{nm})$

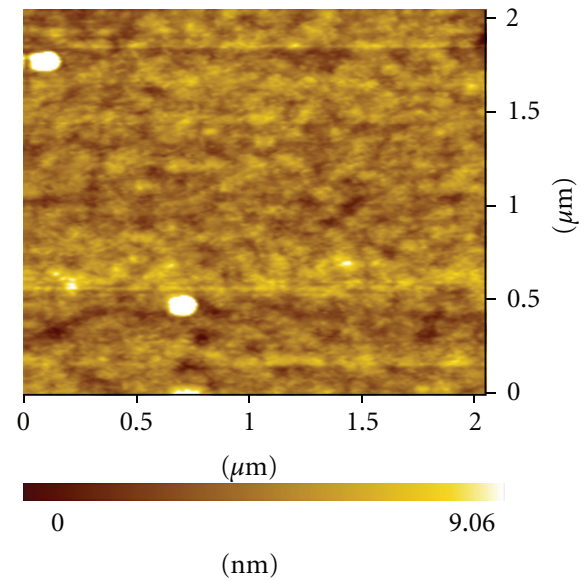

$(\mathrm{nm})$

FIGURE 4: AFM 3d- and 2d-micrographs of Ag-Cu-O films formed at different oxygen partial pressures: (a) $5 \times 10^{-3} \mathrm{~Pa}$, (b) $2 \times 10^{-2} \mathrm{~Pa}$, and (c) $5 \times 10^{-2} \mathrm{~Pa}$.

to presence of metallic silver along with $\mathrm{Ag}_{2} \mathrm{Cu}_{2} \mathrm{O}_{3}$. The low optical transmittance at low oxygen partial pressure was due to the presence of metallic silver along with $\mathrm{Ag}_{2} \mathrm{Cu}_{2} \mathrm{O}_{3}$. The optical transmittance of the films increased from 10 to $60 \%$ (at wavelength $1200 \mathrm{~nm}$ ) with the increase of oxygen partial pressure. The optical absorption edge of the films shifted towards lower wavelength side with the increase of oxygen partial pressure $5 \times 10^{-3}$ to $5 \times 10^{-2} \mathrm{~Pa}$. The optical absorption coefficient $(\alpha)$ of the films was evaluated from the optical transmittance $(T)$ data using the relation

$$
\alpha=\left(\frac{1}{t}\right) \ln T,
$$




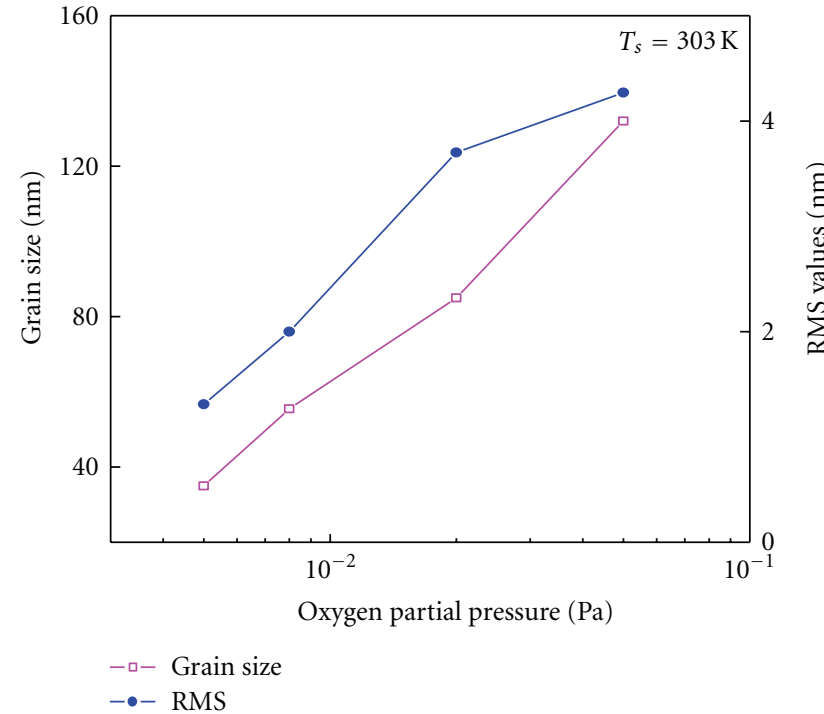

FIGURE 5: Variation in RMS values and grain size of Ag-Cu-O films with the oxygen partial pressure.

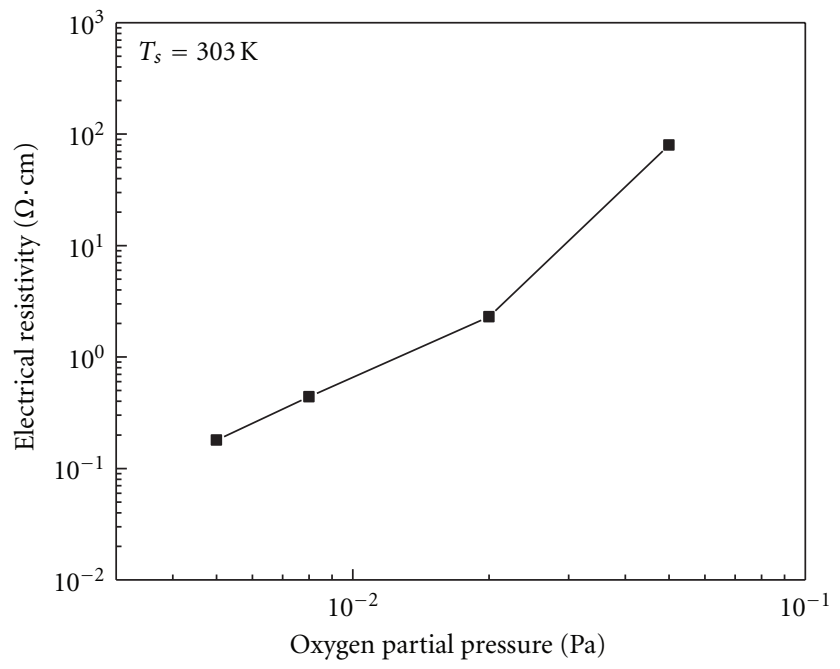

Figure 6: Variation in electrical resistivity of $\mathrm{Ag}-\mathrm{Cu}-\mathrm{O}$ films with oxygen partial pressure.

where $t$ is the film thickness. The optical band gap $\left(E_{g}\right)$ of the films was determined from the optical absorption coefficient and photon energy $(h \nu)$ data assuming the direct transition takes place between the top of the valence band and the bottom of the conduction band using Tauc's relation [22]:

$$
(\alpha h \nu)=A\left(h \nu-E_{g}\right)^{1 / 2},
$$

where $A$ is the absorption edge width parameter. Extrapolation of the linear portion of the plots of $(\alpha h v)^{2}$ versus $h v$ to $\alpha=0$ resulted in the optical band gap of the films.

Figure 8 shows the plots of $(\alpha h v)^{2}$ versus photon energy of the films formed at different oxygen partial pressures. The

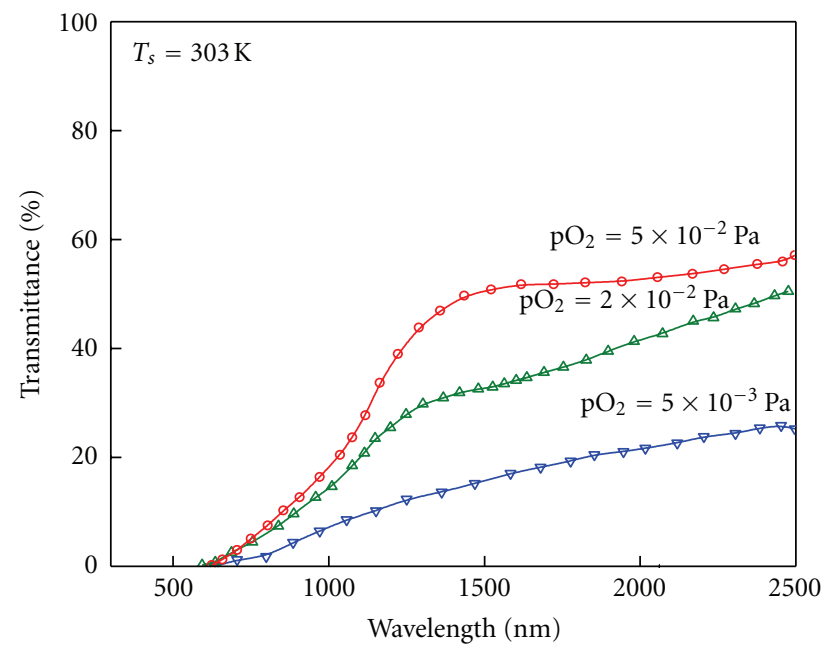

FIgURE 7: Optical transmittance spectra of $\mathrm{Ag}-\mathrm{Cu}-\mathrm{O}$ films formed at different oxygen partial pressures.

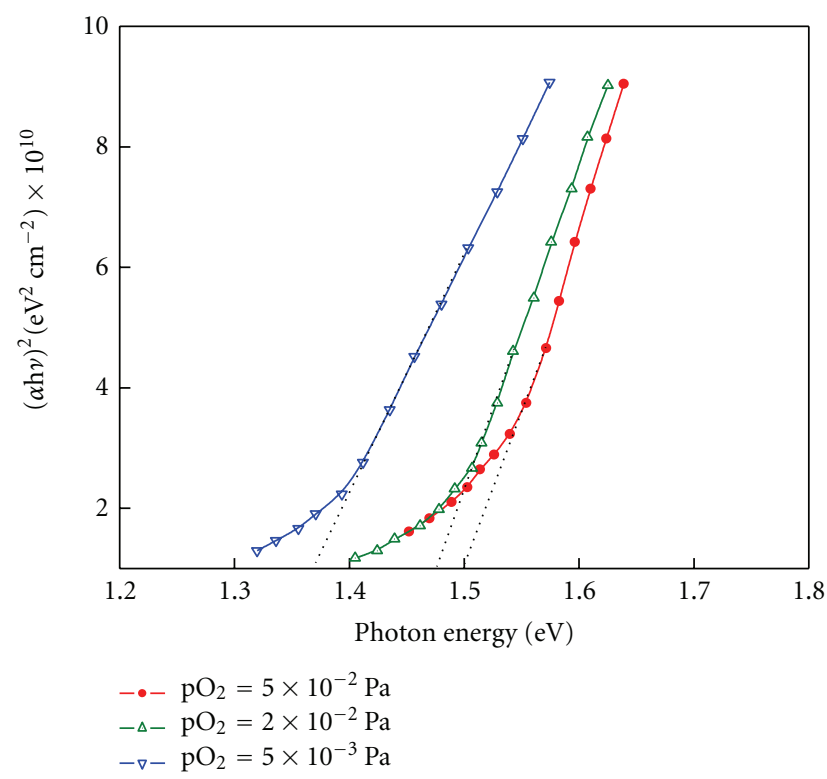

FIGURe 8: Plots of $(\alpha h \nu)^{2}$ versus photon energy $(h \nu)$ of Ag-Cu-O films formed at different oxygen partial pressures.

optical band gap of the films formed at low oxygen partial pressure of $5 \times 10^{-3} \mathrm{~Pa}$ was $1.36 \mathrm{eV}$. The films formed at oxygen partial pressure of $2 \times 10^{-2} \mathrm{~Pa}$ showed the optical band gap of $1.47 \mathrm{eV}$ and increased to $1.50 \mathrm{eV}$ at higher oxygen partial pressure to $5 \times 10^{-2} \mathrm{~Pa}$. In the literature, the reported optical band gap for $\mathrm{Ag}_{2} \mathrm{O}$ films was in the range 1.16$2.25 \mathrm{eV}$ depending on the deposition methods employed and the process parameters maintained during the growth of the films [23, 24]. Rivers et al. [25] achieved a high optical band gap of $3.3 \mathrm{eV}$ in $\mathrm{Ag}_{2} \mathrm{O}$ films formed by evaporation of silver in the presence of electron cyclotron resonance oxygen plasma. 


\section{Conclusions}

RF magnetron sputtering technique was employed for deposition of $\mathrm{Ag}-\mathrm{Cu}-\mathrm{O}$ films on glass substrates by sputtering of $\mathrm{Ag}_{80} \mathrm{Cu}_{20}$ target at different oxygen partial pressures in the range $5 \times 10^{-3}-8 \times 10^{-2} \mathrm{~Pa}$. The influence of oxygen partial pressure on the crystallographic structure and surface morphology, electrical and optical properties was systematically investigated. X-ray diffraction studies of the films formed at oxygen partial pressure $2 \times 10^{-2} \mathrm{~Pa}$ showed the mixed phase of $\mathrm{Ag}_{2} \mathrm{Cu}_{2} \mathrm{O}_{3}$ and $\mathrm{Ag}_{2} \mathrm{Cu}_{2} \mathrm{O}_{4}$ with crystallite size of $15 \mathrm{~nm}$. The grain size of the films determined by AFM increased from 35 to $132 \mathrm{~nm}$ with the increase of oxygen partial pressure from $5 \times 10^{-3}$ to $5 \times 10^{-2} \mathrm{~Pa}$. The root mean square surface roughness of the films determined from atomic force microscope increased from 1.3 to $4.3 \mathrm{~nm}$ with the increase of oxygen partial pressure from $5 \times 10^{-3}$ to $5 \times$ $10^{-2} \mathrm{~Pa}$.

In conclusion, copper silver oxide films formed at oxygen partial pressure of $2 \times 10^{-2} \mathrm{~Pa}$ were mixed ternary phases of $\mathrm{Ag}_{2} \mathrm{Cu}_{2} \mathrm{O}_{3}$ and $\mathrm{Ag}_{2} \mathrm{Cu}_{2} \mathrm{O}_{4}$ showed electrical resistivity of $2.3 \Omega \mathrm{cm}$ and optical band gap of $1.47 \mathrm{eV}$.

\section{Acknowledgments}

The authors are thankful to Professor J. F. Pierson, Institut Jean Lamour, Department CP2S, Ecole des Mines, Nancy University, Nancy, France, for providing XRD and electrical data on these films. One of the authors, A. Sreedhar, is thankful to the University Grants Commission, New Delhi, for the award of Junior Research Fellowship to carry out the present work.

\section{References}

[1] P. Gomez-Romero, E. M. Tejada-Rosales, and M. RosaPalacin, " $\mathrm{Ag}_{2} \mathrm{Cu}_{2} \mathrm{O}_{3}$ : the first silver copper oxide," Angewandte Chemie International Edition, vol. 38, no. 4, pp. 524-525, 1999.

[2] D. Munoz-Rojas, J. Oro, P. Gomez-Romero, J. Fraxedas, and N. Casan-Pastor, "Electrochemically induced reversible solid state transformations: electrosynthesis of $\mathrm{Ag}_{2} \mathrm{Cu}_{2} \mathrm{O}_{4}$ by room temperature oxidation of $\mathrm{Ag}_{2} \mathrm{Cu}_{2} \mathrm{O}_{3}$," Electrochemistry Communications, vol. 4, no. 9, pp. 684-689, 2002.

[3] D. Munoz-Rojas, J. Fraxedas, J. Oro, P. Gomez - Romero, and N. Casan-Pastor, "Structural study of electrochemicallysynthesized $\mathrm{Ag}_{2} \mathrm{Cu}_{2} \mathrm{O}_{4}$. A novel oxide sensitive to irradiation," Crystal Engineering, vol. 5, no. 3-4, pp. 459-467, 2003.

[4] D. Munoz-Rojas, J. Fraxedas, P. Gomez-Romero, and N. Casan-Pastor, "Room Temperature solid state transformation from $\mathrm{Ag}_{2} \mathrm{Cu}_{2} \mathrm{O}_{3}$ to $\mathrm{Ag}_{2} \mathrm{Cu}_{2} \mathrm{O}_{4}$ by ozone oxidation," Journal of Solid State Chemistry, vol. 178, no. 1, pp. 295-305, 2005.

[5] K. Adelsberger, J. Curda, S. Vensky, and M. Jansen, "High-pressure synthesis and electrochemical investigation of $\mathrm{Ag}_{2} \mathrm{Cu}_{2} \mathrm{O}_{3}$," Journal of Solid State Chemistry, vol. 158, no. 1, pp. 82-86, 2001.

[6] E. M. Tejada-Rasales, J. Rodriguez-Carvajal, M. Rosa-Palacin, and P. Gomez-Romero, "Simultaneous neutron and X-Ray refinement of the structure of $\mathrm{Ag}_{2} \mathrm{Cu}_{2} \mathrm{O}_{3}$, the first silver copper oxide," Materials Science Forum, vol. 378, p. 606, 2001.

[7] J. Curda, W. Klein, and M. Jansen, " $\mathrm{AgCuO}_{2}$-synthesis, crystal structure, and structural relationships with $\mathrm{CuO}$ and
$\mathrm{Ag}^{\mathrm{I}} \mathrm{Ag}^{\mathrm{III}} \mathrm{O}_{2}$," Journal of Solid State Chemistry, vol. 162, no. 2, pp. 220-224, 2001.

[8] J. Curda, W. Klein, H. Liu, and M. Jansen, "Structure redetermination and high pressure behaviour of $\mathrm{AgCuO}_{2}$," Journal of Alloys and Compounds, vol. 338, no. 1-2, pp. 99-103, 2002.

[9] C. D. May and J. T. Vaughey, "New cathode materials for silverbased primary batteries: $\mathrm{AgCuO}_{2}$ and $\mathrm{Ag}_{2} \mathrm{Cu}_{2} \mathrm{O}_{3}$," Biochemical and Biophysical Research Communications, vol. 6, p. 1075, 2004.

[10] T. W. Jones, J. S. Forrester, A. Hamilton, M. G. Rose, and S. W. Donne, "Discharge rate capabilities of alkaline $\mathrm{AgCuO}_{2}$ electrode," Journal of Power Sources, vol. 172, no. 2, pp. 962969, 2007.

[11] http://ip.com/patfam/en/29269564.

[12] F. Sauvage, D. Munoz-Rojas, K. R. Poeppelmeier, and N. Casan-Pastor, "Transport properties and lithium insertion study in the p-type semi-conductors $\mathrm{AgCuO}_{2}$ and $\mathrm{AgCu}_{0.5} \mathrm{Mn}_{0.5} \mathrm{O}_{2}$," Journal of Solid State Chemistry, vol. 182, no. 2, pp. 374-380, 2009.

[13] J. Feng, B. Xiao, J. C. Chen, C. T. Zhou, Y. P. Du, and R. Zhou, "Optical properties of new photovoltaic materials: $\mathrm{AgCuO}_{2}$ and $\mathrm{Ag}_{2} \mathrm{Cu}_{2} \mathrm{O}_{3}$," Solid State Communications, vol. 149, no. 3738, pp. 1569-1573, 2009.

[14] S. Ondono-Castillo, P. Gomez-Romero, A. Fuertes, and N. Casan-Pastor, "Electrochemical oxidation of La2CuO4. Phase equilibria among superconductors," in Proceedings of the International Symposium on Soft Chemistry Routes to New Materials, pp. 193-196, September 1993.

[15] P. Narayana Reddy, A. Sreedhar, M. Hari Prasad Reddy, S. Uthanna, and J. F. Pierson, "Process-parameter-dependent structural, electrical, and optical properties of reactive magnetron sputtered Ag-Cu-O films," Journal of Nanotechnology, vol. 2011, Article ID 986021, 8 pages, 2011.

[16] J. Musil, P. Baroch, J. Vlček, K. H. Nam, and J. G. Han, "Reactive magnetron sputtering of thin films: present status and trends," Thin Solid Films, vol. 475, no. 1-2, pp. 208-218, 2005.

[17] R. Syenders, M. Wantelet, R. Gouttebaron, J. P. Dauchat, and D. Hecq, "Experimental and theoretical studies of the DC reactive magnetron sputtering deposition of silver oxide thin films," Surface and Coatings Technology, vol. 174-175, pp. 1282-1286, 2003.

[18] A. S. Reddy, G. V. Rao, S. Uthanna, and P. S. Reddy, "Structural and optical studies on dc reactive magnetron sputtered $\mathrm{Cu}_{2} \mathrm{O}$ films," Materials Letters, vol. 60, no. 13-14, pp. 1617-1621, 2006.

[19] C. Petitjean, D. Horwat, and J. F. Pierson, "Structureproperties relationship in reactively sputtered Ag-Cu-O films," Journal of Physics D, vol. 42, no. 2, Article ID 025304, 2009.

[20] S. Uthanna, M. H. P. Reddy, P. Boulet, C. Petitjean, and J. F. Pierson, "Effect of deposition temperature on the physical properties of RF magnetron sputtered Ag-Cu-O films with various Cu to Ag ratios," Physica Status Solidi (A) Applications and Materials, vol. 207, no. 7, pp. 1655-1659, 2010.

[21] N. Ravi Chandra Raju, K. Jagadeesh Kumar, and A. Subrahmanyam, "Physical properties of silver oxide thin films by pulsed laser deposition: effect of oxygen pressure during growth," Journal of Physics D, vol. 42, no. 13, Article ID 135411, 2009.

[22] J. Tauc, Amorphous and Liquid Semiconductors, Plenum Press, New York, NY, USA, 1974.

[23] A. J. Varkey and A. F. Fort, "Some optical properties of silver peroxide $(\mathrm{AgO})$ and silver oxide $\left(\mathrm{Ag}_{2} \mathrm{O}\right)$ films produced by 
chemical-bath deposition," Solar Energy Materials and Solar Cells, vol. 29, no. 3, pp. 253-259, 1993.

[24] X. Y. Gao, H. L. Feng, L. M. Ma et al., "Analysis of the dielectric constants of the $\mathrm{Ag}_{2} \mathrm{O}$ film by spectroscopic ellipsometry and single-oscillator model," Physica B, vol. 405, no. 7, pp. 19221926, 2010.

[25] S. B. Rivers, G. Bernhardt, M. W. Wright, D. J. Frankel, M. M. Steeves, and R. J. Lad, "Structure, conductivity, and optical absorption of $\mathrm{Ag}_{2-x} \mathrm{O}$ films," Thin Solid Films, vol. 515, no. 24, pp. 8684-8688, 2007. 

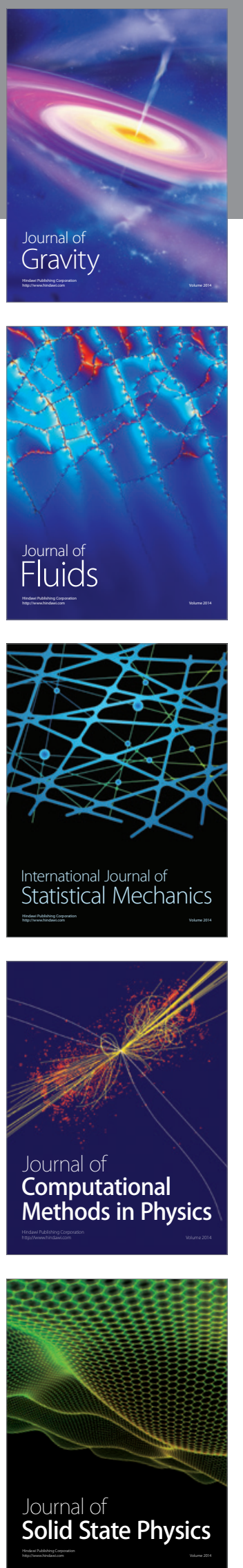
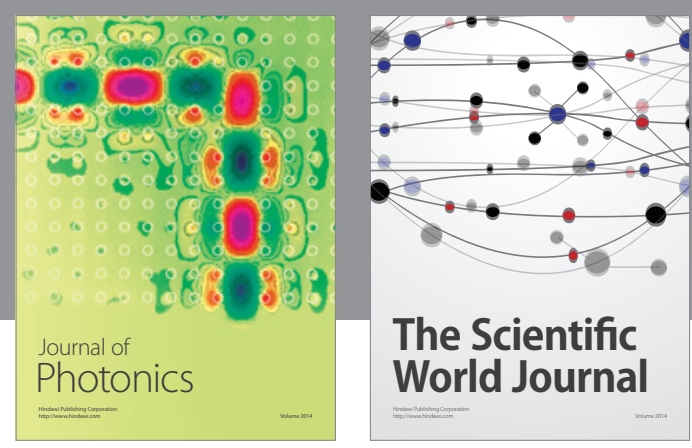

The Scientific World Journal

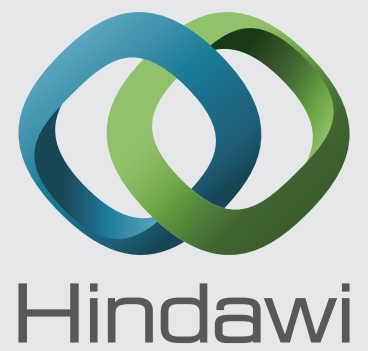

Submit your manuscripts at http://www.hindawi.com
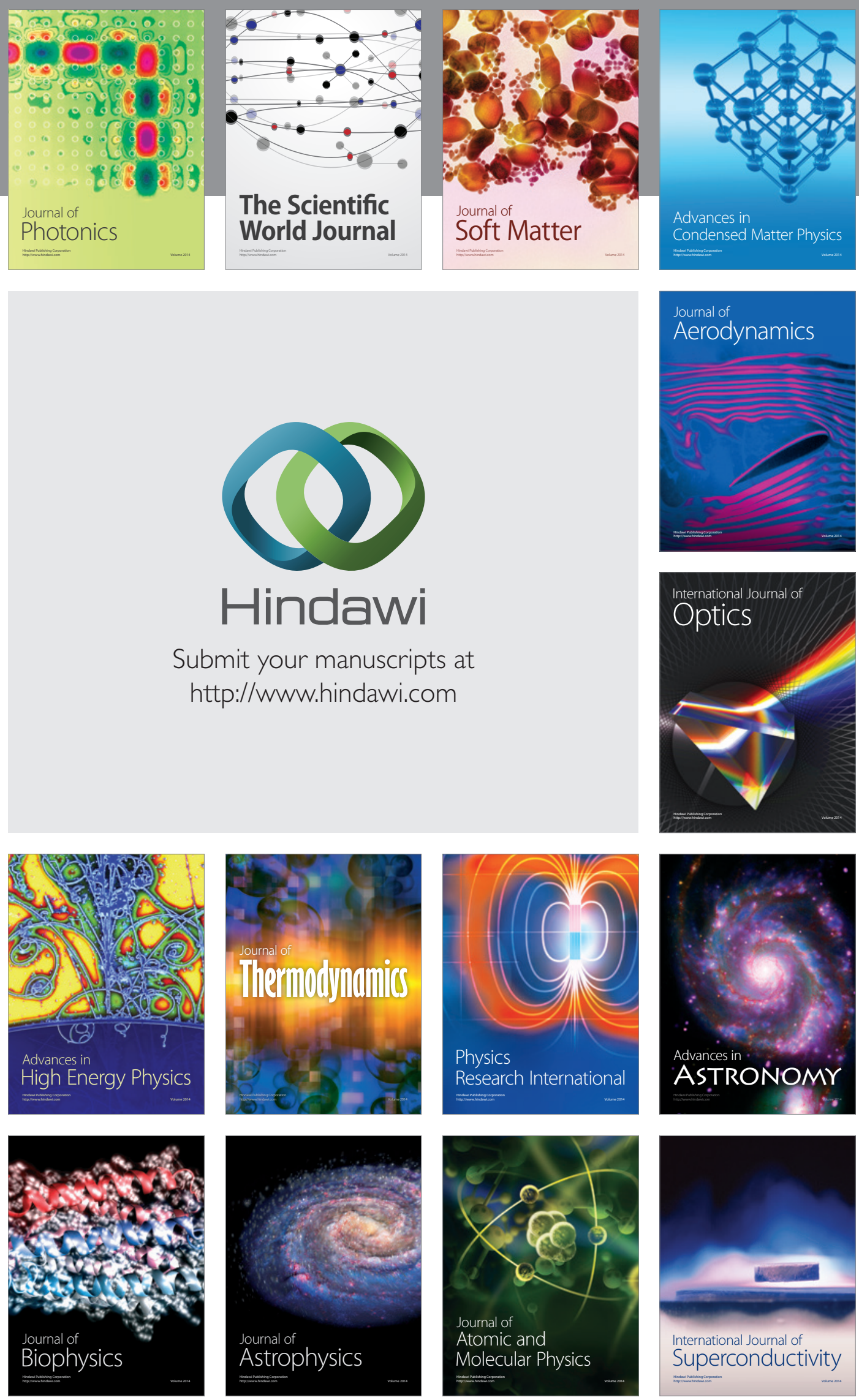
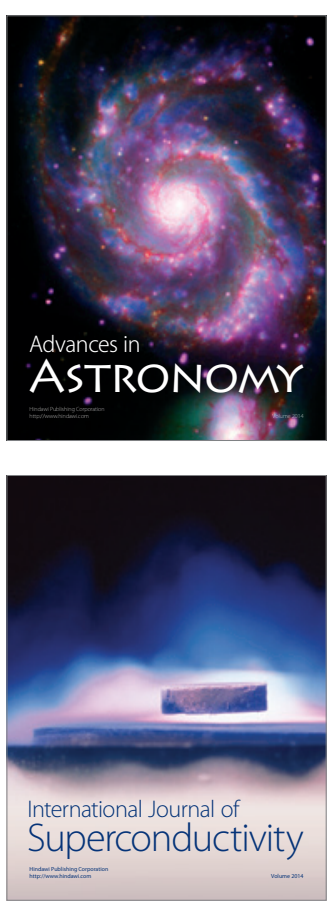